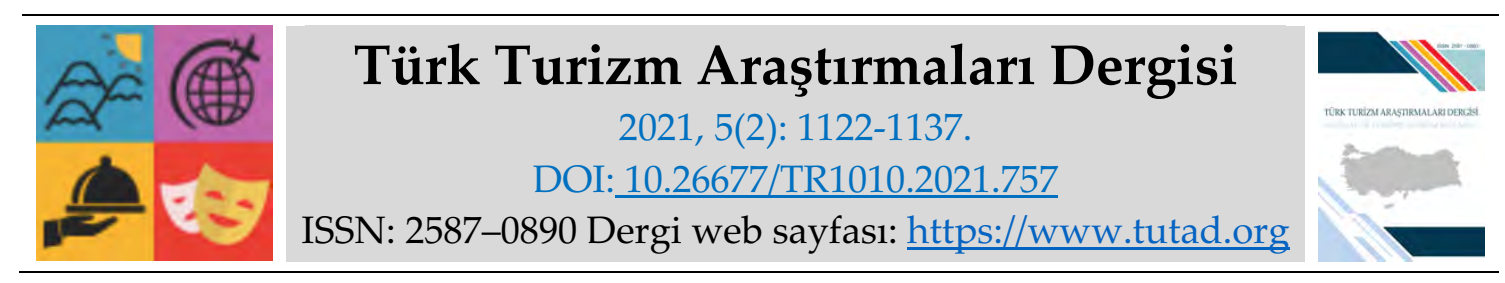

ARASTIRMA MAKALESI

\title{
Aşçılık Bölümü Tercih Nedenleri ile Kişilik İlişkisi
}

Öğr. Gör. Dr. Çağla ÜST CAN, Aksaray Üniversitesi, Güzelyurt Meslek Yüksekokulu, Aksaray, e-posta: caglaust@gmail.com

ORCID: https://orcid.org/0000-0003-0615-5903

Öz

İnsan hayatının büyük kısmını oluşturan iş yaşamının çok farklı sebeplerden etkilenmesi, seçilmeye mecbur kalınan mesleklerin kişileri iş yaşantıları boyunca mutsuz edecek olması ve bunun sonucu olarak gizli işsizlik ve düzgün yapılmayan görevlerin ortaya çıkması kaçınılmazdır. Özellikle hizmet sektöründe en önemli faktör olan işgörenlerin; mesleklerini severek seçmeleri, severek işlerini yapmaları ve işe uygun kişilik özelliklerine sahip olmaları önemlidir. Bu nedenle araştırmanın amacı; üniversite öğrencilerinin bölüm tercihlerini etkileyen faktörlerin belirlenmesi ve bu faktörlerin kişilik özellikleri ile demografik değişkenlere göre nasıl farklılaştığının saptanmasıdır. Araştırmada olasılığa dayalı olmayan yöntemlerden kolayda örnekleme yöntemi kullanılmış ve 252 aşı̧llı bölümü öğrencisine uygulanan anketler SPSS 20 programı ile yorumlanmıştır. Analizler sonucunda; aşçılık öğrencilerinin bölüm tercihini en fazla etkileyen unsurun meslek değerleri olduğu; bölüm seçiminde anne mesleğinin ve anne eğitiminin önemli rol oynadığı; kişilik özelliklerinden alınan en yüksek ortalamanın deneyime açık kişilik olduğu; kişiliğin birçok demografik özelliğe göre farklılık gösterdiği ve farklı kişilik özelliğinde öğrencilerin farklı bölüm tercihi nedenlerinden etkilendiği görülmüştür.

Anahtar Kelimeler: Bölüm Tercihi, Kişilik, Aşçılık.

Makale Gönderme Tarihi: 13.03.2021

Makale Kabul Tarihi: 06.06.2021

\section{Önerilen Atıf:}

Üst Can, Ç. (2021). Aşçıllk Bölümü Tercih Nedenleri ile Kişilik İlişkisi, Türk Turizm Araştırmaları Dergisi, 5(2): 1122-1137.

(C) 2021 Türk Turizm Araştırmaları Dergisi. 


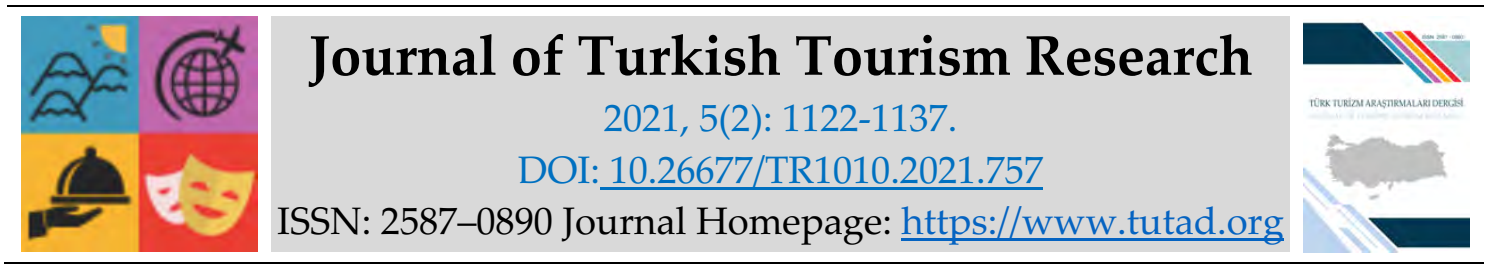

\title{
$\underline{\text { RESEARCH PAPER }}$
}

\section{Personality Relationship with The Reasons for Choosing the Cookery Department}

Dr. Çağla ÜST CAN, Aksaray University, Güzelyurt Vocational School, Aksaray, e-mail: caglaust@gmail.com

ORCID: https://orcid.org/0000-0003-0615-5903

\begin{abstract}
It is inevitable that business life, which constitutes a large part of human life, is affected by many different reasons, and that the professions forced to be selected would make people unhappy throughout their work life, and as a result, hidden unemployment and improper duties would emerge. It is important for employees - especially those who are the most important factor in the service sector - to choose their profession fondly, to do their job fondly, and to have personality traits suitable for the job. For this reason, the purpose of this study is to determine the factors that affect the university students' choice of departments and to determine how these factors differ according to the personality traits of the participants and demographic variables. The "convenience sampling method", one of the non-probabilistic methods, was used in the study and the questionnaires which applied to 252 cookery students were interpreted by using SPSS 20 program. As a result of the analysis; it was observed that the most influencing factor in the choice of the department of the cookery students is the professional values; that maternal profession and education play an important role in the selection of the department; that the highest average taken from personality traits is the personality which is open to experience; and that personality differs according to many demographic characteristics and different personality traits are affected by the reasons of students' choice of different departments.
\end{abstract}

Keywords: Department Preference, Personality, Cookery.

Received: 13.03 .2021

Accepted: 06.06.2021

\section{Suggested Citation:}

Üst Can, Ç. (2021). Personality Relationship with The Reasons for Choosing the Cookery Department, Journal of Turkish Tourism Research, 5(2): 1122-1137.

(C) 2021 Türk Turizm Araştırmaları Dergisi. 


\section{Gíriş}

Kişinin bireysel ve toplumsal rolünün belirlenmesinde etkili olan ve bireyin geleceğinin şekillenmesine yardımcı olan, hayatı süresince yapacağı en önemli tercihlerden birisi meslek seçimidir. Bireyler seçtikleri meslekler ile kendilerini keşfeder ve yeteneklerini ortaya çıkarırlar. Dolayısıyla meslek seçimi, insanın hayatında yapması gereken en önemli seçimler arasında yer almaktadır ve meslek seçiminin ilk aşamalarından birisi ise üniversite bölüm tercihidir. Günümüzde sosyal değişme, sanayileşme ve ekonomik kalkınma seviyelerine paralel olarak pek çok ülkede mesleki davranışların incelenmesi ve dikkatlerin meslek seçimi üzerine yoğunlaşması giderek artan bir eğilim göstermektedir.

Endüstrileşme süreci ile birlikte ortaya çıkan toplumsal değişme çeşitli sorunları da beraberinde getirmektedir. Bu sorunlar siyasal ve ekonomik alandan, gençlerin meslek seçimine kadar uzanan alanlara yansımaktadır. Bireylerin kişisel özellikleri başta olmak üzere, yükseköğretime geçiş sisteminden kaynaklanan etkenler, ailevi faktörler, başarı güdüsü, sosyo-ekonomik düzey, mesleki değerler, cinsiyet, yetenek, ilgi, psikolojik gereksinimler, arkadaş ve çevre ilişkileri gibi faktörler de üniversite bölüm tercihinde etkili olabilmektedir. Bu doğrultuda araştırma; üniversite öğrencilerinin bölüm tercihlerini etkileyen faktörlerin belirlenmesi ve bu faktörlerin katılımcıların kişilik özellikleri ile demografik değişkenlere göre nasıl farklılaştığının saptanması amacıyla yapılmıştır. Araştırma amacına ulaşılmasına katkı sağlayabilmesi açısından nicel araştırma yöntemlerinden anket tekniği kullanılmış ve anketler Aksaray Üniversitesi Aşçılık bölümü Ön Lisans öğrencileri örneklem alınarak veriler toplanmıştır. Çalışmada ilk olarak araştırma konusu içerisine giren kişilik özellikleri ve bölüm tercihi hakkında bilgilere yer verilmiş, daha sonra bulgular çeşitli analizler ile incelenmiş ve son olarak elde edilen sonuçlar alan yazında yer alan farklı çalışmalarla desteklenerek aktarılmıştır.

Araştırmanın Aksaray Üniversitesi'nde ön lisans düzeyinde eğitim gören aşçllık bölümü öğrencilerini örneklem alması, araştırmanın sınırlılı̆̆ıdır. İleride yapılacak olan çalışmaların lisans programlarında, farklı üniversitelerde veya Türkiye geneli bir örneklem ile yapılması araştırma sonuçlarının daha genellenebilir olmasına katkı sağlayabilir. Gönüllülük esasına bağlı olarak araştırmaya katılan tüm öğrencilerin anketleri tarafsızca cevapladığı ve bu nedenle de elde edilen sonuçların güvenilir sonuçlar olduğu araştırmanın varsayımları arasında yer almaktadır. Elde edilen sonuçların alanyazına, turizm sektörüne ve bölüm tercihi aşamasında olan öğrencilere katkı sağlayacağı düşünülmektedir.

\section{LITERATÜR TARAMASI}

Meslek, Arapçadan dilimize geçen bir terim olup, kişinin kendine çalışma alanı edindiği ve geçimini sağlayabilmek amacıyla yaptığı devamlı iş olarak tanımlanmaktadır (Aytekin, 2005:21). Türk Dil Kurumu sözlüğünde meslek; belirli bir eğitim sayesinde kazanılan bilgi ve beceriye dayalı, insanlığa faydalı mal ve hizmet üretmek ve karşılığında para kazanmak için yapılan iş olarak tanımlanmaktadır (Genel Türkçe Sözlük, 2021). Yanıkkerem ve arkadaşları (2004:61) ise mesleği, kişilerin hayatlarını kazanabilmek amacıyla yaptığı, kuralları toplum tarafından belirlenen ve belli bir eğitim sonucu kazanılabilen bilgi ve becerilere dayalı etkinlikler olarak tanımlamaktadır. Bu kapsamda meslek kişinin kimliğinin en önemli parçalarından birisidir ve insanın etrafından saygı görmesine, toplumda yer edinmesine, işe yaradığını hissetmesine ve başkaları ile ilişki kurmasına olanak tanıyan bir etkinlik alanıdır (Kuzgun, 2009:21).

İnsanlar hayatlarını geçmişteki gibi tabiata bağlı olarak kendi kendine sürdüremediğinden toplumdaki diğer bireylerle hem yardımlaşma hem de rekabet içinde olmak zorundadır. Rekabetin giderek arttığı son yıllarda insanların ihtiyaç duyduğu parayı kazanabilmesi için iş 
bulması yani mesleğini seçmesi gerekmektedir (İbiş, 2011:44). Kişinin hayatında önemli bir yeri olan meslek seçimi hem bireysel hem de toplumsal açıdan önem taşımaktadır. Toplumsal gelişime hizmet sunan işgücü planlamasında; kişileri hem topluma hem de kendi bilgi ve becerilerine uygun olarak değerlendirmek ve bu sayede işgücünden en etkin şekilde yararlanmak amacıyla meslek seçimine önem vermek ve genç nesile bu konunun önemi hususunda rehberlik etmek oldukça önemlidir (Yeşilyaprak, 2003:191).

Bireyler; yetenek, ilgi, bilgi, beceri ve istekleri doğrultusunda meslek seçimi yaptığında, iş hayatı boyunca hem mutlu hem de başarılı olacaktır. Kişisel özellikler göz ardı edilerek yapılan meslek seçimi sonrasında bireylerin mutsuz ve başarısız olması kaçınılmazdır. Bu nedenle insanlar meslek seçerken kendi kişisel özellikleri ile seçeceği mesleğin uygunluğu konusunda oldukça dikkat etmelidir. Meslek yalnızca bir para kazanma aracı olarak düşünülmemeli, her şeyden önce yetenekleri kullanma, kendini gerçekleştirme ve geliştirme yolu olarak görülmelidir (Sarıkaya ve Khorshid, 2009:394). Bireylerin meslek seçimlerine etki eden çok sayıda faktör olduğunu ifade eden Deniz (2001:4) bu faktörlerden bazılarının; cinsiyet, hayaller, mesleğin toplumdaki yeri, mesleğe olan talep, aile beklentisi, okul başarısı, öğretmen ve arkadaş görüşleri, kişinin yetenekleri, ailenin sosyo-ekonomik düzeyi, ülkenin ekonomik durumu, meslek hakkında sahip olunan bilgi ve mesleki olgunluk olduğunu belirtmiştir. Öte yandan Ginzberg ve arkadaşları meslek seçiminin kısa bir zaman dilimini içerisine alan bir olay olmadığını ve kişinin çocukluğundan yetişkinliğine kadar devam eden uzun bir süreci ele aldığını ifade etmiştir (Akt. Aydın, 2014:17). İnsanların doğuşundan itibaren gelen ve çevre ile olan etkileşimi sonucu şekillenen ve değişimi çok kolay olmayan özellikler bütünü olarak ifade edilen kişilik (Atak, 2013:312) kavramının da bu kapsamda meslek seçimini etkileyen önemli bir unsur olduğu söylenebilir. Ayrıca bireylerin bölüm/meslek tercihleri ve daha sonrasında seçilen meslekte başarı oranı, kişilik özellikleri ile meslek özellikleri arasındaki uyuma bağlı olduğu da ifade edilmektedir (Momberg, 2005:61). Bu noktada bireylerin sadece meslek seçiminde değil, aynı zamanda mesleklerini başarı ile icra etmelerinde de kişilik önemli bir rol oynadığı söylenebilir.

En temel anlamıyla bir bireyin başkalarına tepki verdiği ve başkalarıyla etkileşim kurduğu yolların toplamı olarak tanımlanan (Alkhelil, 2016:142) kişilik; soyut davranış motifleri ile bireylerin somut davranışları arasında bir araç olan (Güney, 2020:14); insanları birbirinden farklılaştıran, kişinin kendine has davranış, duygu ve düşüncelerinin bir bütünü olarak tanımlanabilir (Macionis, 2003:115). Kişilerarası farklılıkların ortaya konulmasında önemli bir etken olan, oluşumunda çevresel ve genetik faktörlerin etkisinin yüksek olduğu düşünülen kişiliği (Hogan, 2009), 1985 yılında Costa ve McCrae tarafından geliştirilen beş faktörlü kişilik özellikleri (Bilgin, 2011:44) olarak ele almak mümkündür. Kişilikteki bireysel farklılıkların yapısını ve bireyin gelişimini açıklamayı amaçlayan (Costa ve McCrae, 2012:2) beş faktörlü kişilik özelliklerini; dışadönüklük, deneyime açıklık, sorumluluk, yumuşak başlılık ve duygusal dengelilik boyutlarında ele almak mümkündür. Dişadönüklük alt boyutu sosyal, cana yakın, rahat ve girişken kişilik özelliklerini ifade ederken, tam tersi özellikleri barındıran asosyal, mesafeli, içine kapanık kişilik özellikleri ise içe dönük kişilik olarak ifade edilmektedir. Deneyime açıklı, meraklı, yeni duygu ve düşüncelere açık, yaratıcı özellikleri ifade ederken, diğer uç noktada yer alan deneyime açık olmayan bireyler ise geleneksel, tutucu ve sabit fikirli kişilik özelliklerini barındırmaktadır. Sorumluluk alt boyutu disiplinli, azimli, görev bilinci yüksek kişilik özelliklerini ifade ederken, tam tersi özellikleri barındıran disiplinsiz, tembelliğe meyilli ve görev bilincinden uzak olan kişilik ise dağınıklık alt boyutu ile ifade edilmektedir. Yumuşak başlılık alt boyutu özellikle kişilerarası ilişkilerde nazik olma, çatışmalardan kaçınma, yardımseverlik gibi özellikleri barındırırken, diğer uç noktada kindar, geçimsiz, insanlara güvenmeyen ve uzlaşılması zor özellikleri taşıyan kişilik ise hırçınlık olarak ifade edilmektedir. Duygusal dengelilik alt boyutunda kendine güvenen, sakin, kolay kolay öfkelenmeyen özellikler 
yer alırken, duygusal dengesiz kişilikte ise güvensiz, endişeli, gergin bireysel özellikler yer almaktadır (Costa ve McCrae, 1995:21-25; Saltürk, 2008:165-167; Şengel, Pamukçu ve Zengin, 2015:124-125; Doğan, 2013:57-58; Horzum, Ayas ve Padır, 2017:399-400).

Günümüzde yeni mesleklerin ortaya çıkması, bazı mesleklerin yok olması, bazı mesleklerin popülerliği artarken önceden popüler olan mesleklerin popülerliğini kaybediyor olması; temelinde mesleği icra edenlere, mesleğe duyulan ihtiyaca ve teknolojik gelişmelere bağlı olarak değişmektedir. Bu açıdan bakıldığında aşçılık mesleğinin geçmişten günümüze önemini hiç kaybetmediği ve insanlığın varlığı boyunca da kaybetmeyeceğini söylemek mümkündür. Ancak duruma eğitim açısından baktığımızda ise aşçılık bölümünün tercih edilme oranı yüksek bölümler arasında yer almasının yakın geçmişte meydana geldiğini söylenebilir. 2020 yılı itibariyle Türkiye'de devlet üniversitelerinde 70 'den fazla meslek yüksekokulunda ve vakıf üniversitelerinde ise 30'dan fazla meslek yüksekokulunda Aşçllı (Ön lisans) bölümünün aktif olarak öğrenci alımı yaptığı görülmektedir (www.yok.gov.tr). Hertzman ve Mass'a (2012:53) göre son yıllarda yiyecek-içecekle ilgili yapılan televizyon programı sayılarının ve popülaritesinin artması, ünlü şeflerin sektördeki yükselişleri ve mezun olduktan sonra iş bulabilme olanağı kişileri bu mesleğe yönelten nedenler arasında gösterilebilir. Öte yandan özellikle Türkiye'nin turizm potansiyeli ve giderek artan turizm faaliyetlerinin hem sektördeki eleman ihtiyacını hem de bölüme olan ilgiyi artırdığını da söylemek mümkündür.

Turizm faaliyetleri hangi amaçla gerçekleştirilirse gerçekleştirilsin (sağlık, spor, kültür, dinlenme vb.), içerisinde mutlaka bir yeme-içme aktivitesinin olduğu ve turizme katılanların gün geçtikçe gastronomik deneyimlere daha fazla önem verdiği bilinmektedir. Bu açıdan ele alındığında hem mutfak kültürünün tanıtımı hem de buna bağlı olarak ülkenin tanıtımı açısından kültür elçisi gibi görev yapması gereken mutfak çalışanlarının performansı oldukça büyük önem arz etmektedir. Kişilerin çalıştıkları alanda görev bilincine sahip olması ve sahip olunan görevi layıkıyla yerine getirmesi temelinde yatan çoğu faktörle birlikte, kişiliğe uygun meslek seçimi yapılması da önem taşımaktadır. Bu nedenle aşçlık bölümünde öğrenim gören ve dolayısıyla mesleğini aşçılık olarak seçen öğrencilerin; ağırlıklı olarak hangi kişilik özelliğine sahip olduğu, bölümü tercih etme nedenleri, bölüm tercihinin ve kişiliğin demografik özelliklere göre farklılaşıp farklılaşmadığı ve bölüm tercihini etkileyen faktörlerin kişilik özelliklerine göre değişip değişmediğini ortaya çıkarmak amacıyla çalışma gerçekleştirilmiştir. Çalışma sonucunda ise öğrencilerin bölüm tercihini etkileyen faktörlerin hem kişilik özelliklerine hem de demografik değişkenlere göre farklılaştığı görülmüştür.

\section{YÖNTEM}

Verilerin toplanmasında nicel araştırma yöntemlerinden anket tekniğinden yararlanılmıştır ve kullanılan anket üç bölümden oluşmaktadır. Anketin ilk bölümünde; "cinsiyet, yaş, ailenin yaşadığ1 yer, baba eğitim düzeyi, baba mesleği, anne eğitim düzeyi ve anne mesleği" gibi cevaplayıcıların demografik özellikleri ile ilgili 7 soru yer almaktadır. Uygulanan anketin ikinci bölümünde; bölüm tercihlerini etkileyen faktörlerin tespiti amacıyla sorular yer almaktadır ve bu sorular İbiş'in (2011) tez çalışmasında kullandığı, bölüm tercihini etkileyen faktörlerin tespit edilmesini amaçlayan 28 ifadeden oluşmaktadır. Ölçekte, bölüm tercih nedenlerini etkileyen unsurlar; yetenek, ilgi, meslek değerleri, psikolojik gereksinim, başarı güdüsü, sosyo-ekonomik düzey, aile-arkadaş-çevre ilişkileri, cinsiyet ve yükseköğretime geçiş sistemi olmak üzere 9 alt boyutta ele alınmaktadır. Anketin üçüncü ve son bölümünde ise Atak'ın (2013) Türk kültürüne uyarladığı kişilik ölçeği kullanılmıştır. 10 maddeden oluşan ölçek; deneyime açıklık, yumuşak başlılık, duygusal dengelilik, sorumluluk ve dişadönüklük olmak üzere beş farklı kişilik boyutunda ele alınmıştır. 
Araştırma evrenini, Aksaray Üniversitesi Güzelyurt Meslek Yüksekokulu Aşçllık programında 2019 yılında halen aktif olarak eğitim görmekte olan 1. ve 2. sınıf öğrencileri (yaklaşık 200 öğrenci) ve 2019 yılına kadar mezun olmuş öğrenciler (yaklaşık 500 öğrenci) oluşturmaktadır. Araştırmada 0,05 hata payı ile belirli evrenler için kabul edilebilen örneklem büyüklügü (700 kişi için 248 anket) dikkate alınarak (Altunışık vd., 2012:137), 2019 yılı Eylül-Kasım ayları arasında olasılığa dayalı olmayan örnekleme yöntemlerinden kolayda örnekleme yöntemiyle toplanmış, anketler öğrencilere yüz yüze ve online olarak ulaştırılmış ve hedeflenen sayıya ulaşıldığında anket uygulanması bırakılmıştır (Altunışık vd., 2012:142). Araştırma sürecinde elde edilen anketlerden eksiksiz olarak doldurulan 252 anket ise araştırmaya dahil edilmiştir. Elde edilen verilerin değerlendirilmesi SPSS 20 programı ile yapılmış ve sonuçlar yorumlanmaya çalışılmıştır.

\section{BULGULAR}

Araştırma bulgularına geçmeden önce kullanılan ölçeğin güvenilirliği, Cronbach Alfa $(\alpha)$ katsayısının hesaplanması yöntemiyle tespit edilmiştir. Bu doğrultuda, bölüm tercihlerini etkileyen faktörlerin tespiti için kullanılan ölçeğe ilişkin güvenilirlik katsayısı, $\alpha=0,8847$ olarak; beş faktörlü kişilik özelliklerinin tespiti amacıyla kullanılan ölçeğe ilişkin güvenilirlik katsayısı ise, $\alpha=0,9254$ olarak hesaplanmıştır. Özellikle sosyal bilimler alanında yapılan araştırmalarda bu katsayının 0,80'ın üzerinde olması sonucun yüksek derecede güvenilir olduğu anlamına gelmektedir (Kalayc1, 2009).

Tablo 1. Katılımcıların Demografik Özellikleri

\begin{tabular}{|c|c|c|c|c|c|c|c|}
\hline & & $\mathbf{N}$ & $\%$ & & & $\mathbf{N}$ & $\%$ \\
\hline \multirow[t]{3}{*}{ Cinsiyet } & Erkek & 129 & 51 & \multirow{5}{*}{$\begin{array}{l}\text { Ailenin } \\
\text { Aylık } \\
\text { Geliri }\end{array}$} & 2.400 TL ve alt1 & 39 & 16 \\
\hline & Kadın & 123 & 49 & & $2.401-3.901 \mathrm{TL}$ & 99 & 39 \\
\hline & Toplam & 252 & 100 & & $3.902-5.402 \mathrm{TL}$ & 71 & 28 \\
\hline \multirow[t]{5}{*}{ Yaş } & $18-20$ yaş arası & 4 & 1 & & 5.403 TL ve üstü & 43 & 17 \\
\hline & $21-23$ yaş arası & 58 & 21 & & Toplam & 252 & 100 \\
\hline & $24-26$ yaş arası & 81 & 29 & \multirow{5}{*}{$\begin{array}{l}\text { Ailenin } \\
\text { Yaşadığ1 } \\
\text { Yer }\end{array}$} & Şehir & 136 & 54 \\
\hline & 27 yaş ve üstü & 65 & 24 & & İlçe & 86 & 34 \\
\hline & Toplam & 252 & 100 & & Kasaba & 5 & 2 \\
\hline \multirow{4}{*}{$\begin{array}{l}\text { Annenin } \\
\text { Eğitim } \\
\text { Düzeyi }\end{array}$} & İlköğretim & 177 & 70 & & Köy & 25 & 10 \\
\hline & Ortaöğretim & 42 & 17 & & Toplam & 252 & 100 \\
\hline & Yükseköğretim & 33 & 13 & \multirow{4}{*}{$\begin{array}{l}\text { Babanın } \\
\text { Eğitim } \\
\text { Düzeyi }\end{array}$} & İlköğretim & 108 & 43 \\
\hline & Toplam & 252 & 100 & & Ortaöğretim & 97 & 38 \\
\hline \multirow{9}{*}{$\begin{array}{l}\text { Annenin } \\
\text { Mesleği }\end{array}$} & Memur & 18 & 7 & & Yükseköğretim & 47 & 17 \\
\hline & Öğretmen & 7 & 3 & & Toplam & 252 & 100 \\
\hline & Emekli & 2 & 0,8 & \multirow{7}{*}{$\begin{array}{l}\text { Babanın } \\
\text { Mesleği }\end{array}$} & Memur & 55 & 22 \\
\hline & Esnaf & 3 & 1,2 & & Öğretmen & 7 & 3 \\
\hline & Serbest Meslek & 8 & 3,2 & & Emekli & 14 & 5 \\
\hline & Ev hanımı & 212 & 84 & & Esnaf & 33 & 13 \\
\hline & Terzi & 2 & 0,8 & & Serbest meslek & 62 & 25 \\
\hline & \multirow[t]{2}{*}{ Toplam } & \multirow[t]{2}{*}{252} & \multirow[t]{2}{*}{100} & & İşçi & 72 & 29 \\
\hline & & & & & Doktor & 9 & 3 \\
\hline
\end{tabular}


Araştırmada ilk olarak aşçılık bölümü öğrencilerinin demografik özelliklerinin incelenmesi amacıyla frekans analizi yapılmış ve Tablo 1'de verilmiştir. Tablo incelendiğinde; öğrencilerin \%51'inin (129 kişi) erkek, \%49'unun (123 kişi) ise kadınlardan oluştuğu ve \%58'inin yaşlarının 2123 yaş aralığında olduğu görülmektedir. Öte yandan öğrencilerin yarıdan fazlasının ailesinin şehir merkezinde yaşadığı (\%54) ve aylık gelirlerinin de 2.401-3.901 TL (\%39) aralığında olduğu görülmüş̧ür. Ailenin eğitim düzeyine bakıldığında ise öğrencilerin \% $38^{\prime}$ inin babası ortaöğretim mezunu iken, \%43'ünün annesi ilköğretim mezunudur. Öğrencilerin babalarının ağırlıklı olarak İşçi (\%29) ve Serbest Meslek (\%25) çalışanı olarak görev yaptığı; büyük çoğunluğunun annesinin ise ev hanımı (\%84) olduğu görülmüştür.

Üniversite öğrencilerinin bölüm tercihlerini etkileyen faktörlerin belirlenmesi amacıyla yöneltilen 28 soru; yetenek, ilgi, meslek değerleri, psikolojik gereksinimler, başarı güdüsü, sosyoekonomik düzey, aile-arkadaş-çevre ilişkileri, cinsiyet ve yükseköğretime geçiş sistemi olmak üzere dokuz alt boyuta ayrılmaktadır. Boyutlara ilişkin ortalamaların tespiti amacıyla frekans analizi yapılmış ve Tablo 2 'de gösterilmiştir. Analiz sonucunda öğrencilerin bölüm seçimlerini en yüksek düzeyde etkileyen alt boyutun meslek değerleri (maddi kazanç düzeyi, toplumsal saygınlık düzeyi ve meslekte ilerleme imkanları) $(\bar{x}=3,88)$ olduğu görülmektedir. Öğrencilerin seçtikleri bölümden mezun olduktan sonra meslekte elde edeceği kazanç, mesleğin toplumsal saygınlık düzeyi ve meslekte ilerleme imkanları tercihlerini en yüksek düzeyde etkileyen durum olarak ortaya çıkmıştır. Öğrencilerin tercihlerini etkileyen diğer faktörlere ilişkin aritmetik ortalamalara puan sıralamasına göre bakıldığında ise; Psikolojik Gereksinim $\bar{x}=3,52$, Başarı Güdüsü $\bar{x}=3,43$, Sosyo-Ekonomik Düzey $\bar{x}=3,33$, İlgi $\bar{x}=3,32$, Cinsiyet $\bar{x}=3,28$, Yetenek $\bar{x}=3,23$, Yükseköğretime Geçiş Sistemi $\bar{x}=3,14$ ve Aile-Arkadaş-Çevre İlişkileri ise $\bar{x}=3,09$ puan değerine sahiptir. Araştırmanın ikinci kısmında öğrencilerin kişilik özelliklerinin belirlenmesi amacıyla yöneltilen 10 soru; deneyime açıklık, yumuşak başlılık, duygusal dengelilik, sorumluluk ve dışadönüklük olmak üzere beş faktöre ayrılmaktadır. Yapılan frekans analizi sonucunda ise öğrencilerin en belirgin kişilik özelliklerinin deneyime açıklık $(\bar{x}=3,56)$ olduğu görülmüştür. Diğer kişilik özelliklerinin aritmetik ortalamalarına bakıldığında ise; Duygusal Dengelilik $\bar{x}=3,22$, Sorumluluk $\bar{x}=2,94$, Dişadönüklük $\bar{x}=2,93$ ve Yumuşak Başlılığın ise $\bar{x}=2,93$ ortalamaya sahip olduğu görülmektedir.

Tablo 2. Bölüm Tercihini Etkileyen Faktörler ve Kişilik Özellikleri Boyutlarına Ait Frekans Analizi

\begin{tabular}{|c|c|c|c|c|}
\hline & Boyutlar & $\mathrm{n}$ & Ortalama & $\begin{array}{l}\text { Standart } \\
\text { Sapma }\end{array}$ \\
\hline \multirow{9}{*}{$\begin{array}{l}\text { Bölüm Tercihini } \\
\text { Etkileyen Faktörler }\end{array}$} & Yetenek & 252 & 3,23 & 868 \\
\hline & İlgi & 252 & 3,32 & 874 \\
\hline & Meslek Değerleri & 252 & 3,88 & 879 \\
\hline & Psikolojik Gereksinim & 252 & 3,52 & ,919 \\
\hline & Başarı Güdüsü & 252 & 3,43 & 853 \\
\hline & Sosyo-Ekonomik Düzey & 252 & 3,33 & 900 \\
\hline & Aile-Arkadaş-Çevre İlişkileri & 252 & 3,09 & 883 \\
\hline & Cinsiyet & 252 & 3,28 & ,956 \\
\hline & Yükseköğretime Geçiş Sistemi & 252 & 3,14 & 1,028 \\
\hline \multirow{5}{*}{ Kişilik Özellikleri } & Dişadönüklük & 252 & 2,93 & ,784 \\
\hline & Yumuşak Başlılık & 252 & 2,93 & ,780 \\
\hline & Sorumluluk & 252 & 2,94 & 604 \\
\hline & Duygusal Dengelilik & 252 & 3,22 & ,701 \\
\hline & Deneyime Açılık & 252 & 3,56 & 878 \\
\hline
\end{tabular}


Katılımcıların demografik özellikleri ile bölüm tercihlerine etki eden nedenler ve kişilik özellikleri arasında bir farklılığın olup olmadığını saptamak amacıyla farklılık analizleri (T Testi ve ANOVA) yapılarak Tablo 3 ve Tablo 4'de gösterilmiştir. Yapılan analizler sonucunda bölüm tercihlerini öğrencilerin cinsiyet, yaş, ailenin yaşadığı yer, ailenin gelir düzeyi, baba eğitim durumu ve baba mesleğinin etkilemediği; yalnızca anne eğitim düzeyi ve anne mesleği arasında bir farklılığın saptandığı görülmüştür. Öte yandan kişilik özellikleri ve demografik özellikler ile yapılan farklılık testleri sonucunda cinsiyet, yaş, anne mesleği ve baba mesleği değişkenleri ile farklılık saptanmazken; ailenin aylık geliri, ailenin yaşadığı yer, anne eğitim düzeyi ve baba eğitim düzeyi arasında farklılıklar saptanmıştır.

Anne eğitim düzeyi ile ilgi ve sosyo-ekonomik düzey alt boyutları arasında saptanan farklılıklara bakıldığında; anne eğitim düzeyi yüksek olan öğrencilerin bölüm tercihlerinde ilgi alanlarına yönelme konusunda pozitif yönde etkilendikleri ve bölümlerini kendi ilgilerine uygun alanlardan seçtikleri görülmüştür. Öte yandan anne eğitim düzeyi yüksek olan öğrenciler bölüm tercihlerinde, ileride sahip olunacak mesleğin sosyal ve ekonomik düzeylerini dikkate aldıkları görülmektedir.

Tablo 3. Bölüm Tercihi ile Anne Eğitim Düzeyi Arasındaki Farklılık Analizi

\begin{tabular}{|c|c|c|c|c|c|c|c|}
\hline Bölüm Tercihi & Anne Eğitimi & $\mathbf{N}$ & $\overline{\mathbf{X}}$ & $\begin{array}{c}\text { Standart } \\
\text { Sapma }\end{array}$ & F & $\mathbf{P}^{*}$ & $\begin{array}{c}\text { Anlam } \\
\text { Fark1 }\end{array}$ \\
\hline \multirow{3}{*}{ İlgi } & İlköğretim & 177 & 3,26 & 881 & \multirow{3}{*}{4,11} & \multirow{3}{*}{, $017^{*}$} & \multirow{3}{*}{$\mathrm{c}-\mathrm{a}$} \\
\hline & Ortaöğretim & 42 & 3,25 & 892 & & & \\
\hline & Yükseköğretim & 33 & 3,72 & 714 & & & \\
\hline \multirow{3}{*}{$\begin{array}{l}\text { Sosyo- } \\
\text { Ekonomik } \\
\text { Düzey }\end{array}$} & İlköğretim & 177 & 3,27 & ,854 & \multirow{3}{*}{3,68} & \multirow{3}{*}{, $027^{*}$} & \multirow{3}{*}{$\mathrm{c}-\mathrm{a}$} \\
\hline & Ortaöğretim & 42 & 3,32 & 827 & & & \\
\hline & Yükseköğretim & 33 & 3,70 & 806 & & & \\
\hline
\end{tabular}

Anne mesleği ile bölüm tercihi arasındaki farklılık analizinin yer aldığı Tablo 4'e bakıldığında; yetenek, sosyo-ekonomik düzey, başarı güdüsü ve aile-arkadaş-çevre ilişkileri alt boyutları arasında farklılık saptanmıştır. Bu farklılığın görüldüğü gruplar incelendiğinde ise annesi öğretmen olan öğrencilerin bölüm tercihlerinde; yeteneğe uygunluğun, sosyo-ekonomik imkânların, başarılı olunabileceği inancının ve aile-arkadaş-çevre tavsiyelerinin annesi emekli olan öğrencilerden daha fazla etkili olduğu görülmüştür.

Tablo 4. Bölüm Tercihi ile Anne Mesleği Arasındaki Farklılık Analizi

\begin{tabular}{|c|c|c|c|c|c|c|c|}
\hline Bölüm Tercihi & Anne Mesleği & $\mathbf{N}$ & $\overline{\mathbf{X}}$ & $\begin{array}{c}\text { Standart } \\
\text { Sapma } \\
\end{array}$ & $\mathbf{F}$ & $\mathbf{P}^{*}$ & $\begin{array}{c}\text { Anlam } \\
\text { Fark1 } \\
\end{array}$ \\
\hline \multirow{2}{*}{ Yetenek } & Öğretmen & 7 & 3,76 & 498 & \multirow{2}{*}{2,25} & \multirow{2}{*}{,039* } & \multirow{2}{*}{$a-b$} \\
\hline & Emekli & 2 & 1,50 & ,235 & & & \\
\hline \multirow{2}{*}{$\begin{array}{c}\text { Sosyo-Ekonomik } \\
\text { Düzey }\end{array}$} & Öğretmen & 7 & 4,38 & 448 & \multirow{2}{*}{2,53} & \multirow{2}{*}{, $021^{*}$} & \multirow{2}{*}{$a-b$} \\
\hline & Emekli & 2 & 2,33 & ,000 & & & \\
\hline \multirow{2}{*}{ Başarı Güdüsü } & Öğretmen & 7 & 4,14 & 878 & \multirow{2}{*}{2,20} & \multirow{2}{*}{, $043^{*}$} & \multirow{2}{*}{$a-b$} \\
\hline & Emekli & 2 & 1,83 & ,707 & & & \\
\hline \multirow{2}{*}{$\begin{array}{l}\text { Aile-Arkadaş- } \\
\text { Çevre İlişkileri }\end{array}$} & Öğretmen & 7 & 3,92 & ,672 & \multirow{2}{*}{3,20} & \multirow{2}{*}{, $005^{*}$} & \multirow{2}{*}{$a-b$} \\
\hline & Emekli & 2 & 1,50 & 707 & & & \\
\hline
\end{tabular}


Kişilik özellikleri açısından demografik farklılıklar ele aldığında demografik birçok faktörün kişilik özelliklerini etkilediği görülmektedir. Öğrencilerin ailesinin aylık geliri ve yaşadığı yer, anne eğitim durumu ve baba eğitim durumunun kişilik özellikleri alt boyutlarında farklılıklara sebep olduğu sonucuna ulaşılmıştır. Bu sonucun yer aldığı Tablo 5 'de görüldüğgü gibi; ailenin aylık geliri ile sorumluluk ve deneyime açıklık kişilik özellikleri arasında fark vardır. Burada ailesinin aylık geliri 2.400 TL ve altı olan öğrencilerin, 2.401-3.901 TL aylık geliri olan öğrencilerden daha fazla sorumluluk sahibi oldukları; ailesinin aylık geliri 5.403 TL ve üstü olan öğrencilerin ise $2.400 \mathrm{TL}$ ve altı olan öğrencilere oranla daha fazla deneyime açık oldukları görülmüştür.

Tablo 5. Kişilik Özellikleri ile Ailenin Aylık Geliri Arasındaki Farklılık Analizi

\begin{tabular}{|c|c|c|c|c|c|c|c|}
\hline $\begin{array}{c}\text { Kişilik } \\
\text { Özellikleri }\end{array}$ & $\begin{array}{c}\text { Ailenin Aylık } \\
\text { Geliri }\end{array}$ & $\mathbf{N}$ & $\overline{\mathbf{X}}$ & $\begin{array}{c}\text { Standart } \\
\text { Sapma }\end{array}$ & $\mathbf{F}$ & $\mathbf{P}^{*}$ & Anlam Fark1 \\
\hline \multirow{4}{*}{ Sorumluluk } & 2.400 TL ve altı & 39 & 3,19 & 832 & \multirow{4}{*}{2,98} & \multirow{4}{*}{, $032^{*}$} & \multirow{4}{*}{$a-b$} \\
\hline & $2.401-3.901 \mathrm{TL}$ & 99 & 2,91 & ,771 & & & \\
\hline & 3.902-5.402 TL & 71 & 2,80 & 808 & & & \\
\hline & 5.403 TL ve üstü & 43 & 2,90 & 692 & & & \\
\hline \multirow{4}{*}{$\begin{array}{l}\text { Deneyime } \\
\text { Açıklık }\end{array}$} & 2.400 TL ve altı & 39 & 3,32 & ,949 & \multirow{4}{*}{3,25} & \multirow{4}{*}{, $022^{*}$} & \multirow{4}{*}{$d-a$} \\
\hline & 2.401-3.901 TL & 99 & 3,47 & ,918 & & & \\
\hline & $3.902-5.402 \mathrm{TL}$ & 71 & 3,61 & ,907 & & & \\
\hline & 5.403 TL ve üstü & 43 & 3,87 & ,535 & & & \\
\hline
\end{tabular}

Ailenin yaşadığı yer ile kişilik özellikleri arasında ortaya çıan farklılıklar Tablo 6'da gösterilmektedir. Ailenin yaşadığı yer ile dışadönüklük ve yumuşak başlılık kişilik özellikleri arasında saptanan farklılığın; köyde, ilçede ve şehirde yaşayan öğrencilerden kaynaklandığı, köyde yaşayan öğrencilerin şehirde ve ilçede yaşayanlara göre daha fazla dışadönük olduklarl; ayrıca köyde yaşayan öğrencilerin şehirdeki öğrencilere oranla daha yumuşak başlı oldukları görülmüştür.

Tablo 6. Kişilik Özellikleri ile Ailenin Yaşadığı Yer Arasındaki Farklılık Analizi

\begin{tabular}{|c|c|c|c|c|c|c|c|}
\hline $\begin{array}{c}\text { Kişilik } \\
\text { Özellikleri }\end{array}$ & $\begin{array}{c}\text { Ailenin } \\
\text { Yaşadığı Yer }\end{array}$ & $\mathbf{N}$ & $\overline{\mathbf{X}}$ & $\begin{array}{c}\text { Standart } \\
\text { Sapma }\end{array}$ & $\mathbf{F}$ & $\mathbf{P}^{*}$ & Anlam Farkı \\
\hline \multirow{4}{*}{ Dışadönüklük } & Şehir & 136 & 2,83 & ,794 & \multirow{4}{*}{4,51} & \multirow{4}{*}{, $004^{*}$} & \multirow{4}{*}{$\begin{array}{l}d-a \\
d-b\end{array}$} \\
\hline & İlçe & 86 & 2,91 & ,727 & & & \\
\hline & Kasaba & 5 & 3,10 & 651 & & & \\
\hline & Köy & 25 & 3,44 & ,781 & & & \\
\hline \multirow{4}{*}{ Yumuşak Başlılık } & Şehir & 136 & 2,84 & ,772 & \multirow{4}{*}{3,04} & \multirow{4}{*}{, $030^{*}$} & \multirow{4}{*}{$d-a$} \\
\hline & İlçe & 86 & 2,95 & ,716 & & & \\
\hline & Kasaba & 5 & 2,70 & ,447 & & & \\
\hline & Köy & 25 & 3,34 & ,965 & & & \\
\hline
\end{tabular}

Anne eğitim düzeyi ve baba eğitim düzeyi ile kişilik arasında oluşan farklılıklar Tablo 7'de verilmiştir. Anne eğitim düzeyi ile dışadönük kişilik özelliği arasında oluşan farklılığa 
bakıldığında, annesi ilköğretim mezunu olan öğrencilerin annesi ortaöğretim ve yükseköğretim mezunu olan öğrencilerden daha dışadönük kişilik özelliğine sahip olduğu görülmektedir. Ayrıca baba eğitim düzeyi ile oluşan farklılığa bakıldığında ise; babası ilköğretim mezunu olan öğrencilerin, babası ortaöğretim ve yükseköğretim mezunu olan öğrencilere göre daha dışadönük, sorumluluk sahibi ve duygusal dengeli olduğu; aynı zamanda babası ilköğretim mezunu olan öğrencilerin ortaöğretim mezunu olan öğrencilere göre daha yumuşak başlı olduğu görülmüştür.

Tablo 7. Kişilik Özellikleri ile Anne ve Baba Eğitim Düzeyi Arasındaki Farklılık Analizi

\begin{tabular}{|c|c|c|c|c|c|c|c|}
\hline $\begin{array}{c}\text { Kişilik } \\
\text { Özellikleri }\end{array}$ & Anne Eğitimi & $\mathbf{N}$ & $\overline{\mathbf{X}}$ & $\begin{array}{c}\text { Standart } \\
\text { Sapma }\end{array}$ & $\mathbf{F}$ & $\mathbf{P}^{*}$ & Anlam Farkı \\
\hline \multirow{3}{*}{ Dişadönüklük } & İlköğretim & 177 & 3,06 & ,715 & \multirow{3}{*}{8,72} & \multirow{3}{*}{, $000^{*}$} & \multirow{3}{*}{$\begin{array}{l}a-b \\
a-c\end{array}$} \\
\hline & Ortaöğretim & 42 & 2,47 & ,748 & & & \\
\hline & Yükseköğretim & 33 & 2,75 & ,944 & & & \\
\hline $\begin{array}{c}\text { Kişilik } \\
\text { Özellikleri }\end{array}$ & Baba Eğitimi & $\mathbf{N}$ & $\overline{\mathbf{X}}$ & $\begin{array}{c}\text { Standart } \\
\text { Sapma }\end{array}$ & $\mathbf{F}$ & $\mathbf{P}^{*}$ & Anlam Farkı \\
\hline \multirow{3}{*}{ Dişadönüklük } & İlköğretim & 108 & 3,19 & ,735 & \multirow{3}{*}{3,73} & \multirow{3}{*}{, $000^{*}$} & \multirow{3}{*}{$\begin{array}{l}a-b \\
a-c\end{array}$} \\
\hline & Ortaöğretim & 97 & 2,74 & ,688 & & & \\
\hline & Yükseköğretim & 47 & 2,69 & ,900 & & & \\
\hline \multirow{3}{*}{$\begin{array}{l}\text { Yumuşak } \\
\text { Başlilık }\end{array}$} & İlköğretim & 108 & 3,17 & ,905 & \multirow{3}{*}{5,53} & \multirow{3}{*}{, $000^{*}$} & \multirow{3}{*}{$a-b$} \\
\hline & Ortaöğretim & 97 & 2,58 & ,640 & & & \\
\hline & Yükseköğretim & 47 & 3,09 & ,370 & & & \\
\hline \multirow{3}{*}{ Sorumluluk } & İlköğretim & 108 & 3,10 & ,634 & \multirow{3}{*}{2,64} & \multirow{3}{*}{, $001^{*}$} & \multirow{3}{*}{$\begin{array}{l}a-b \\
a-c\end{array}$} \\
\hline & Ortaöğretim & 97 & 2,81 &, 587 & & & \\
\hline & Yükseköğretim & 47 & 2,80 & ,472 & & & \\
\hline \multirow{3}{*}{$\begin{array}{l}\text { Duygusal } \\
\text { Dengelilik }\end{array}$} & İlköğretim & 108 & 3,49 & 897 & \multirow{3}{*}{4,76} & \multirow{3}{*}{, $000^{*}$} & \multirow{3}{*}{$\begin{array}{l}a-b \\
a-c\end{array}$} \\
\hline & Ortaöğretim & 97 & 2,93 & ,403 & & & \\
\hline & Yükseköğretim & 47 & 3,15 & ,347 & & & \\
\hline
\end{tabular}

Araştırmaya katılan öğrencilerin bölüm tercihlerini etkileyen faktörler ile kişilik özellikleri arasındaki farklılığın incelendiği analiz sonucunda, bölüm tercihini etkileyen sosyo-ekonomik düzey ve aile-arkadaş-çevre ilişkileri ile kişilik arasında farklılık olduğu görülmüştür. Bölüm tercihini etkileyen sosyo-ekonomik düzey ile sorumluluk ve yumuşak başlllık kişilik özelliği arasında farklılığın olduğu ve sorumluluk kişilik özelliğine sahip olan öğrencilerin bölüm tercihlerinde yumuşak başlı kişilik özelliğindeki öğrencilere oranla bölümün sosyo-ekonomik düzeyinin daha fazla etkili olduğu görülmüştür. Öte yandan bölüm tercihini etkileyen ailearkadaş-çevre ilişkileri alt boyutu ile kişilik özellikleri arasında anlamlı farklılık istatistiksel olarak saptanmış olmasına rağmen, farklılığın hangi kişilik özelliklerinden kaynaklandığı tespit edilememiştir. Ancak ortalamalar dikkate alınarak bir yorum yapılacak olursa; sorumluluk ve deneyime açıklık kişilik özelliğindeki kişilerin dışadönüklük, yumuşak başlılık ve duygusal dengelilik kişilik özelliğindeki öğrencilere oranla bölüm tercihlerinde aile-arkadaş ve çevre ilişkilerinden daha fazla etkilendikleri söylenebilir. 
Tablo 8. Bölüm Tercihi ile Kişilik Özellikleri Arasındaki Farklılık Analizi

\begin{tabular}{|c|c|c|c|c|c|c|c|}
\hline $\begin{array}{l}\text { Bölüm } \\
\text { Tercihi }\end{array}$ & Kişilik Özellikleri & $\mathbf{N}$ & $\overline{\mathbf{X}}$ & $\begin{array}{c}\text { Standart } \\
\text { Sapma }\end{array}$ & $\mathbf{F}$ & $\mathbf{P}^{*}$ & Anlam Farkı \\
\hline \multirow{5}{*}{$\begin{array}{c}\text { Sosyo- } \\
\text { Ekonomik } \\
\text { Düzey }\end{array}$} & Dişadönüklük & 24 & 3,16 & 862 & \multirow{5}{*}{2,80} & \multirow{5}{*}{, $026^{*}$} & \multirow{5}{*}{$c-b$} \\
\hline & Yumuşak Başlılık & 38 & 3,06 & 899 & & & \\
\hline & Sorumluluk & 28 & 3,64 & 690 & & & \\
\hline & Duygusal Dengelilik & 45 & 3,22 & ,755 & & & \\
\hline & Deneyime Açıklık & 117 & 3,43 & 879 & & & \\
\hline \multirow{5}{*}{$\begin{array}{c}\text { Aile- } \\
\text { Arkadaş- } \\
\text { Çevre } \\
\text { İlişkileri }\end{array}$} & Dişadönüklük & 24 & 2,72 & ,793 & \multirow{5}{*}{3,85} & \multirow{5}{*}{, $005^{*}$} & \multirow{5}{*}{-} \\
\hline & Yumuşak Başlılık & 38 & 2,80 & ,941 & & & \\
\hline & Sorumluluk & 28 & 3,37 & 826 & & & \\
\hline & Duygusal Dengelilik & 45 & 2,97 & 802 & & & \\
\hline & Deneyime Açıklık & 117 & 3,23 & 849 & & & \\
\hline
\end{tabular}

Son olarak kişilik özelliklerine göre ayrılan öğrencilerin, bölüm tercihi yaparken etkilendikleri en önemli faktörün belirlenmesi amacıyla yapılan analiz sonucunda; dışadönüklük, yumuşak başlılık ve sorumluluk kişilik özelliğine sahip öğrencilerin meslek değerleri faktöründen; duygusal dengelilik ve deneyime açıklık kişilik özelliğindeki öğrencilerin ise psikolojik gereksinim faktöründen etkilendikleri görülmüş ve analiz sonucu Tablo 9'da verilmiştir. Dışadönüklük, yumuşak başlılık ve sorumluluk kişilik özelliğine sahip olan öğrencilerin bölümlerini tercih ederken bölümün sağlayacağı maddi kazanç düzeyi, toplumsal saygınlık düzeyi ve meslekte ilerleme imkânlarını dikkate aldıkları; duygusal dengelilik ve deneyime açılık kişilik özelliğindeki öğrencilerin ise bölümün kendilerini mutlu etmesi, mezun olunca sahip olunacak mesleğin yeni ve değişik şeyler yapma ihtiyacını karşılayacak olması ve bu mesleğin bireye huzur verecek olmasının daha etkili olduğu söylenebilir.

Tablo 9. Kişilik Özelliklerine Göre Ayrılan Öğrencilerin En Yüksek Bölüm Tercih Nedenleri Analizi

\begin{tabular}{|c|c|c|c|c|}
\hline Kişilik Özellikleri & Bölüm Tercihi & $(\mathrm{N})$ & Mean $(\vec{x})$ & Standart Sapma \\
\hline Dişadönüklük & \multirow{3}{*}{ Mesleki Değer } & 24 & 3,43 & 898 \\
\hline Yumuşak Başlilık & & 38 & 3,59 & ,974 \\
\hline Sorumluluk & & 28 & 3,97 & ,725 \\
\hline Duygusal Dengelilik & \multirow{2}{*}{ Psikolojik Gereksinimler } & 45 & 3,59 & 887 \\
\hline Deneyime Açıklık & & 117 & 3,68 & 890 \\
\hline
\end{tabular}

\section{SONUÇ ve ÖNERILER}

Yapılan frekans ve farklılık analizlerden yola çıkarak öğrencilerin üniversite bölüm ve dolayısıyla meslek seçimlerinde kişilik özelliklerinin, ilgi ve yeteneklerinin yanı sıra çok sayıda faktörden etkilendiği görülmektedir. Bölüm tercihi yaparken kişilerin ilgi alanlarına yönelmesi, yeteneklerine uygun iş seçmesi, yapacağı işi başarabileceğine olan inancı ve meslekten elde edeceği sosyal, ekonomik ve bireysel kazanımları dikkate alması oldukça önemlidir. Yapılan analizler sonucunda öğrencilerin bölüm seçimlerini en yüksek düzeyde etkileyen alt boyutun meslek değerleri (maddi kazanç düzeyi, toplumsal saygınlık düzeyi ve meslekte ilerleme 
imkanları) ( $\bar{x}=3,88)$ olduğu görülmüştür. Elde edilen bu sonuç İbiş'in (2011) çalışmasında meslek seçimini etkileyen en önemli faktörün "meslek değerleri" $(\bar{x}=3,50)$ olması; Sarıkaya ve Khorshid'in (2009) çalışmasında ortaya çıkan en önemli faktörlerden birinin "meslek değerleri" olması ve Kartal ve arkadaşlarının (2019) çalışmasında meslek seçimini etkileyen en önemli faktörün ise "işin toplumda gördügü itibar" olması ile paralellik göstermektedir. Öte yandan aşı̧lık bölümü tercih nedenlerini inceleyen bir çalışmada elde edilen "iş bulma kolaylığı ve yüksek kazanç" tercih sebepleri araştırmada elde edilen mesleki değerler boyutu ile paralellik göstermektedir (Şahin ve Arman, 2014). İçigen ve Geçgin'in (2021) gastronomi ve mutfak sanatları bölümü öğrencilerini tercih nedenlerine göre iki gruba ayırdığı çalışmasında, bir grupta yer alan öğrencilerin ilgisi ve yeteneği olmasa dahi meslekten elde edecekleri kazanç ve yükselme imkânı (mesleki değer boyutu) gibi sebeplerle bölümü seçmiş olmaları araştırma sonucuyla paralellik gösterir niteliktedir. Şengel ve arkadaşlarının (2015) çalışmasında bölüm tercihini etkileyen önemli unsurlardan birkaçının meslek itibarı (saygınlık) ve kariyer fırsatı (ilerleme) olduğu görülmektedir ve elde edilen bu sonuç araştırma ile paralellik göstermektedir. Ayrıca Erdem ve Kayran (2013) çalışmalarında da turizm ve otelcilik yüksekokulundaki öğrencilerin yarıdan fazlasının (\%54) "ilerleme imkânı yüksek olduğu için" bölümü tercih ettikleri sonucuna ulaşmıştır. Araştırmadan elde edilen sonuçlar ve alan yazında yer alan diğer çalışmaların sonuçları göstermektedir ki; iş bulma imkânının, kariyer yapmanın, kalite yaşam şartlarının ve sosyal statü kazanmanın gittikçe zorlaşması ve aslında gün geçtikçe sahip olunmasının önem kazanmasından dolayı öğrenciler mesleklerini seçerken, eğitim alacakları bölümlerin bu unsurları sağlayacak özellikte olmasına önem göstermiştir.

Araştırmadan elde edilen bir diğer sonuç; meslek seçiminde bireylerin ailelerinin ve aslında annelerinin çok önemli bir rolü olduğudur. Anne eğitimi ve anne mesleği ile bölüm tercihleri arasında farklılıkların saptandığı araştırma sonucu; İbiş'in (2011) çalışmasında elde ettiği "anne eğitimi ile bölüm tercihini etkileyen sosyo-ekonomik düzey arasında istatistiki anlamlı fark bulunmuştur" sonucu ile; Sarıkaya ve Khorshid'in (2009) çalışmasında elde ettiği "anne eğitim düzeyi arttıkça, meslek avantajlarının ön planda tutularak seçim yapılması oranı artmaktadır" sonucu ile paralellik göstermektedir. Öte yandan Bilgin (2011) ise çalışmasında anne eğitimi ile öğrencilerin bölüm tercihinde etkili olan kolaylık değişkeni ve istihdam değişkeni arasında anlamlı bir etkileşim olduğu sonucuna ulaşılmış olması araştırma bulgularını destekler nitelik taşımaktadır. Ayrıca Sarıkaya ve Khorshid'in (2009) sözü geçen çalışmasında anne mesleği ile öğrencilerin meslek seçim nedenleri arasında (meslek avantajları, meslek hakkındaki görüşler, çevredekilerin tavsiyeleri) farklılıklar ortaya çıtığı görülmüştür. Bu verilerden hareketle öğrencilerin bölüm tercihlerinde aile içerisinde özellikle annelerin oldukça büyük etki yarattı̆̆ 1 söylenebilir. Annelerin çocuklarının tüm hayatlarını yönlendirme konusunda etkisinin olmasının yanı sıra, onların geleceklerini şekillendiren en önemli unsur olan bölüm tercihlerine de etki ediyor olması muhtemel bir sonuç olarak karşımız çıkmaktadır ve bu etkinin önemi yadsınmamalıdır.

Kişilik özelliği insanın doğduğu andan itibaren tüm hayatı boyunca gelişmeye devam eden ve aslında bir taraftan da tüm hayatına etki eden önemli bir faktördür. Sosyal hayat gibi iş hayatını da etkileme düzeyi yüksek olan kişilik özelliklerinin dikkate alınması, iş alanı açısından ele alındığında hangi kişilik özelliklerinin nerede başarılı olacağı ve nasıl mutlu olacağının tespiti açısından önemli görülmektedir. Bireylerin kişiliklerinin oluşmasında etki eden unsurların ailenin geliri, yaşadığı yer, anne ve baba eğitimi olduğu araştırma bulgularından elde edilen sonuçlardandır. Analizler sonucunda elde edilen "ailenin aylık geliri kişilik özelliklerini etkilemektedir" bulgusu; Keleş ve Çakır Keleş'in (2017) çalışmasında elde ettiği “ailenin gelir seviyesi arttıkça öğrencilerin deneyime açıklık kişilik özelliklerinin artmaktadır" sonucu ile benzerlik göstermektedir. Çalışmadan elde edilen bir başka sonuç ise aşçılık bölümünü tercih 
eden öğrencilerin ağırlıklı olarak, kişinin hayal gücü ve özgünlük derecesi ile ilgili özelliklerini ifade eden (Brown vd., 2002:112), deneyime açık kişilik özelliğine sahip olmasıdır. Mesleki Yeterlilik Kurumu Ulusal Meslek Standardı (2010:8) aşçıyı; "İşletme ve bölüm izlekleri doğrultusunda, standart reçete ve menü hazırlama, yerel, ulusal ve dünya mutfaklarına ait çorba ve konsomeleri, sıcak ve soğuk sosları, hamur işi yemeklerini, et ve su ürünleri yemeklerini, sebze ve kuru baklagillerden yapılan yemekleri, zeytinyağlıları, pilav ve makarnaları, sıcak-soğuk mezeleri, salataları, garnitürleri ve tatlıları reçete/menülere ve hijyen kurallarına uygun olarak hazırlama ve servis için sunuma hazır hale getirme bilgi ve becerisine sahip olan kişidir. Ayrıca bölümle ilgili bütçe hazırlama, bölümü sevk ve idare etme, eğitimler düzenleme ve verme konularında da amirlerine yardımcı olmalıdır" şeklinde tanımlanmıştır. Kapsamlı bir şekilde ele alınan bu tanımdan da anlaşılacağı gibi, aşçılık bölümünü tercih eden öğrencilerin baskın kişilik özelliğinin deneyime açılık olması aslında görev tanımlarının eksiksiz yerine gelmesi için bir gereklilik olarak görülebilmelidir.

Aşçllık bölümünü seçen kişilerin deneyime açık olmasının; mesleğin gerektirdiği yaratıcılık, farklı lezzetleri deneyimleyebilme, farklı kültürlere ilgi duyma ihtimallerinin daha yüksek olacağı ve böylece sektörde başarı yakalayabilme şanslarının artıracağını düşündürmektedir. Öte yandan mutfak departmanında çalışan bireylerin usta-çırak ilişkisi içerisinde görev yapması, çıraklık yapan işgörenlerin bilgiye gözlem, deneyim ve taklit yoluyla ulaşmasını da gerekli kılmaktadır. Bu noktada aşçılık yapmak isteyen bireylerin deneyimlere açı ve yaratıcı kişilik özelliğinde olması oldukça önemli görülmektedir. Aşçılık eğitimi alan öğrenciler üzerinde yapılan bazı araştırmalarda da benzer sonuçlar elde edildiği görülmektedir. Kalkan ve Tüfekçi'nin (2020) çalışmasında ( $\bar{x}=3,88)$ ve Kalenderoğlu'nun (2017) çalışmasında $(\bar{x}=3,92)$ aşçılık öğrencilerinin; Çetin ve Şahin'in (2018) çalışmasında ise aşçıların ( $\bar{x}=3,57)$ kişilik özelliklerinden deneyime açıklık özelliği ortalamalarının yüksek olduğu görülmektedir. Ayrıca Doğan ve Yeşiltaş'ın (2017) çalışmasında elde ettiği, aşçı ve aşçı olmak isteyen kişilerde bulunması gereken en önemli beş özellikten birinin "Değişim ve Yeniliğe Açık Olmak" şeklinde ortaya çıkması da araştırma sonucunu destekler niteliktedir. Öte yandan turizm sektöründe hangi tür kişilik özelliğine sahip çalışanların daha fazla kariyer yapmak istediğini ortaya koymayı amaçlayan çalışmasında Temeloğlu ve Aksu (2016) sorumluluk, uyumluluk ve deneyime açıklık kişiliğindeki öğrencilerin turizmde kariyer yapma isteğinin daha fazla olduğunu saptamıştır. Aşçılık tanımından yola çıkılarak ele alınan meslekte, başarıya ulaşabilmenin temelinde yatan unsurlardan birinin de farklılıklara/deneyimlere açıklık olduğunu söylemek mümkündür.

Son olarak hangi kişilik özelliğinin bölüm tercihinde ağırlıklı olarak hangi faktörden etkilendiğinin tespit edilmesi amacıyla yapılan analiz sonucunda ise dışadönük, yumuşak başlı ve sorumluluk kişilik özelliğindeki bireylerin mesleki değerler faktörüne; duygusal dengelilik ve deneyime açıklık kişilik özelliğindeki bireylerin ise psikolojik gereksinimler faktörüne önem verdiği görülmüştür. Şengel ve arkadaşlarının (2015) çalışmasında elde ettiği "kişilik ile bölüm tercihi arasında orta düzeyli bir korelasyon vardır" sonucu araştırma bulgularının temelini destekler niteliktedir. Ayrıca araştırmalarında çalışma ile benzer sonuçlar elde eden Silva (2006), otel işletmesi çalışanlarından dışadönük ve sorumluluk kişilik özelliğinde olanların ücret faktöründen (mesleki değerler) etkilendiği sonucuna ulaşması; Bilgin (2011) ise, sorumluluk kişilik özelliğindeki öğrencilerin kolay iş bulma imkânı, maddi kazanç düzeyi gibi ekonomik faktörleri dikkate alması ve sorumluluk ve yumuşak başlılık kişilik özelliğine sahip kişilerin meslekte ilerleme imkânları, çeşitli yerlerde ve büyük şehirlerde iş bulma imkânını dikkate alması ile sorumluluk ve yumuşak başlılık kişilik özelliğindeki öğrencilerin mesleki değerleri dikkate alarak bölüm seçimi sapması sonucu ile paralellik göstermektedir.

İnsan hayatının büyük bir kısmını oluşturan iş yaşamının çok farklı sebeplerden etkilenmesi, seçilmeye mecbur kalınan meslekler kişileri iş yaşantıları boyunca mutsuz edecek ve bunun 
sonucu olarak da gizli işsizlik ve düzgün yapılmayan görevler ortaya çıkacaktır. Bu durumun önlenebilmesi amacıyla bölüm ve dolayısıyla meslek seçiminin doğru yapılabilmesi için öncelikle kişinin kendini tanımasına yardımcı olunmalı ve öğrenciler özellikle üniversite bölüm tercihi esnasında (lise son sınıfta ve üniversite tercihleri sırasında) bölümler hakkında (bölümün olduğu üniversiteler, eğitim içerikleri, bölümün gelecekte sağlayacağı sosyo-ekonomik koşullar, mezun olunca sahip olunabilecek iş alanı ve sınırları gibi) çok iyi bilinçlendirilmelidir. Etkili bir bilgilendirme amacıyla bu süreçte öğrencilere meslekleri tanıtma amaçlı seminerler ve konferanslar verilmeli veya ilgi duyulan mesleğe sahip olan kişiler ile öğrencilerin fikir alışverişi yapması sağlanarak kendisi ile seçmeyi düşündüğü mesleğin nitelikleri arasındaki uygunluğu (kişilik-iş uyumu) araştırmasına yardımcı olunmalıdır. Ayrıca meslek seçiminde büyük etkisi olan aileler, özellikle anneler ise meslekler konusunda detaylı bir şekilde bilinçlendirilmelidir. Emek faktörünün oldukça büyük önem arz ettiği hizmet sektöründe işgörenlerden daha yüksek performans elde etme, personel devir hızını düşürme, verimliliği ve müşteri memnuniyetini artırmak isteyen işletmelerin, personel seçim aşamasında kişilik analizi testlerinden faydalanarak, hangi kişilik özelliğine sahip işgörenlerin başvuru yaptığını, mesleği seçmelerini etkileyen faktörlerin neler olduğunu, kariyer planlarını öğrenmeleri ve bu sayede işletme amaçları doğrultusunda işgörenlerin yönlendirilmelerini sağlaması önemli görülmektedir.

\section{KAYNAKÇA}

Alkhelil, A. H. (2016). The Relationship Between Personality Traits and Career Choice: A Case Study of Secondary School Students, International Journal of Academic Research in Progressive Education and Development, 5(2): 139-152.

Altunışık, R., Coşkun, R., Bayraktaroğlu, S. ve Yıldırım, E. (2012). Sosyal Bilimlerde Araştırma Yöntemleri SPSS Uygulamalı. (7. Baskı), Sakarya: Sakarya Kitabevi.

Atak, H. (2013). The Turkish Adaptation of The Ten-Item Personality Inventory, Archives of Neuropsychiatry, 50: 312-319.

Aydın, Ç. (2014). Üniversite Öğrencilerinde Kariyer Kararsızlı̆̆ının Özsaygı, Denetim Odağı ve Mükemmeliyetçilik Bakımından İncelenmesi, Yayınlanmış Yüksek Lisans Tezi, Ankara Üniversitesi, Ankara.

Aytekin, A. (2005). Meslek Seçimini Etkileyen Sosyo-Ekonomik ve Kültürel Faktörler: Isparta Örneği, Yayınlanmış Yüksek Lisans Tezi, Süleyman Demirel Üniversitesi, Isparta.

Bilgin, Y. (2011). Turizmde Lisans Öğrenimi Gören Öğrencilerin Kişilik Özellikleri ve Mesleğge Yönelik Düşünceleri Üzerine Bir Alan Araştırması, Yayınlanmış Yüksek Lisans Tezi, Düzce Üniversitesi, Düzce.

Brown, T. J., Women, J. C., Donavan, D. T. and Licata, J. W. (2002). The Customer Orientation of Service Workers: Personality Trait Effects on Self and Supervisor Performance Ratings, Journal of Marketing Research, 39: 110-119.

Costa, P. T. and McCrae, R. R. (1995). Domains and Facets: Hierarchical Personality Assessment Using the Revised NEO Personality Inventory, Journal of Personality Assessment, 64(1):21-50.

Costa, P. T. and McCrae, R. R. (2012). The Five-Factor Model, Five Factor Theory and Interpersonal Psychology. [Online] https://www.researchgate.net/publication/286535058 [Erişim Tarihi: 10.02.2021].

Çetin, S. A. ve Şahin, B. (2018). Aş̧̧ıların Beş Faktör Kişilik Özellikleri ile Bireysel İnovasyon Algısı İlişkisi, Journal of Tourism and Gastronomy Studies, 6(4): 419-447. 
Deniz, S. (2001). Bireyin Meslek Seçimini Etkileyen Kaynaklar: Yeni Teknolojilerden İnternet, Muğla Üniversitesi SBE Dergisi, 6: 1-9.

Doğan, S. ve Yeşiltaş, M. (2017). Aşçının Kişilik Özellikleri ile Mesleki Yetkinliklerinin Tespitine Yönelik Bir Çalışma, Journal of Tourism and Gastronomy Studies, 5(4): 250-263.

Doğan, T. (2013). Beş Faktör Kişilik Özellikleri ve Öznel İyi Oluş, Doğuş Üniversitesi Dergisi, 14(1): 56-64.

Erdem, B. ve Kayran, M. F. (2013). Balıkesir Üniversitesi Turizm ve Otelcilik Yüksekokulu Öğrencilerinin Meslek Seçimini Etkileyen Faktörler Üzerine Bir Araştırma, C. Ü. İktisadi ve İdari Bilimler Dergisi, 14(1): 81-106.

Genel Türkçe Sözlük (2021). Meslek. [Online] https://sozluk.gov.tr/ [Erişim Tarihi: 18.02.2021].

Güney, S. (2020). Davranış Bilimleri. (12. Baskı), Ankara: Nobel Akademik Yayıncılık.

Hertzman, J. L. and Mass, J. (2012). The Value of Culinary Education: Evaluating Educational Costs, Job Placement Outcomes and Satisfaction with Value of Associate Degree Culinary and Baking Arts Program Graduates, Journal of Culinary Science \& Technology, 10: 53-74.

Hogan, R. (2009). Kişilik ve Kurumlarm Kaderi. (Çeviren, Baltaş, A.) İstanbul: Remzi Kitabevi.

Horzum, M. B., Ayas, T. ve Padır, M. A. (2017). Beş Faktör Kişilik Ölçeğinin Türk Kültürüne Uyarlanması, Sakarya University Journal of Education, 7(2): 398-408.

İbiş, E. (2011). Öğrencilerin Üniversite Bölüm Tercihleri ve Kariyer Yönelimleri Arasındaki İlişkiye Dair Bir Araştırma, Yayınlanmış Yüksek Lisans Tezi, İstanbul Üniversitesi, İstanbul.

İçigen, M. ve Geçgin, E. (2021). Gastronomi ve Mutfak Sanatları Bölümü Öğrencilerinin Meslek Seçimlerinde Etkili Olan Aile Yakın Çevre Faktörlerinin İncelenmesi, IBAD Sosyal Bilimler Dergisi, 9: 391-414.

Kalaycı, Ş. (2009). Uygulamalı Çok Değişkenli İstatistik Teknikleri. (4. Basım), Ankara: Asil Yayıncılık.

Kalenderoğlu, M. E. (2017). Aşçılık Eğitimi Alan Öğrencilerin Demografik Özellikleri ile Kişilik Tutumları Arasındaki İlişki, Journal of Strategic Research in Social Science, 3(4): 271-280.

Kalkan, G. ve Tüfekci, Ö. K. (2020). Turizm Sektöründe Hizmet Verme Yatkınlığı ve Kişilik İlişkisi, Journal of Applied Tourism Research, 1(2): 133-150.

Kartal, K. S., Ayyıldız, E. ve Alp, S. (2019). Meslek Seçimini Etkileyen Faktörler ile Kariyer Planlama/Tercih Kriterleri Arasındaki İlişkinin İncelenmesi, İstanbul Ticaret Üniversitesi Girişimcilik Dergisi, 3(5): 29-50.

Keleş, Y. ve Çakır Keleş, M. (2017). Turizm Öğrencilerinin Kişilik Özellikleri: Türkiye'de Lisans Düzeyinde Turizm Eğitimine Yönelik Bir Değerlendirme, The Journal of Academic Social Science Studies, 62: 417-428.

Kuzgun, Y. (2009). Meslek Gelişimi ve Danışmanlığı. (3. Basım), Ankara: Nobel Yayıncılık.

Macionis, J. J. (2003). Sociology. (9. Press), New Jersey: Pearson Education.

Mesleki Yeterlilik Kurumu (2010). Ulusal Meslek Standardı Aşçı (Seviye 4). Referans Kodu: 10UMS0110-4. Resmi Gazete Tarih-Sayı: 29.12.2010-27800 (2. Mükerrer).

Momberg, C. (2005). The Relationship Between Personality Traits and Vocational Interests in A South African Context, Master Commerce, University of Pretoria, South Africa. 
ÖSYM (2020). 2020-Yükseköğretim Programları ve Kontenjanları Kılavuzu. [Online] https://www.osym.gov.tr/TR,19431/2020-yuksekogretim-kurumlari-sinavi-yks-yuksekogretimprogramlari-ve-kontenjanlari-kilavuzu.html [Erişim Tarihi: 15.03.2021].

Saltürk, M. (2008). Yönetim Başarısı ve Kişilik. (1. Basım), İstanbul: Toplumsal Dönüşüm Yayınları.

Sarıkaya, T. ve Khorshid, L. (2009). Üniversite Öğrencilerinin Meslek Seçimini Etkileyen Etmenlerin İncelenmesi: Üniversite Öğrencilerinin Meslek Seçimi, Türk Eğitim Bilimleri Dergisi, 7(2): 393-423.

Silva, P. (2006). Effects of Disposition on Hospitality Employee Job Satisfaction and Commitment, International Journal of Contemporary Hospitality Management, 18(4): 317-328.

Şahin, T. ve Arman, A. (2014). Ön Lisans Seviyesinde Aşçıllk Eğitimini Tercih Etme Nedenlerinin Değerlendirilmesi, Akademik Bakı̧̧ Dergisi, 41: 1-12.

Şengel, Ü., Pamukçu, H. ve Zengin, B. (2015). Bölüm Tercihi ile Kişilik Arasındaki İlişki: Kastamonu Üniversitesi Turizm Fakültesi Örneği, Kastamonu Üniversitesi İktisadi ve İdari Bilimler Fakültesi Dergisi, 7: 122-134.

Yanıkkerem, E., Altınparmak, S. ve Karadeniz, G. (2004). Gençlerin Meslek Seçimini Etkileyen Faktörler ve Benlik Saygıları: Manisa Sağlık Yüksekokulu Örneği, Nursing Forum Dergisi, 7: 6162.

Yeşilyaprak, B. (2003). Eğgitimde Rehberlik Hizmetleri: Gelişimsel Yaklaşım. (6. Baskı), Ankara: Nobel Yayın Dağıtım. 